\title{
TEACHERS ATTITUDE TOWARDS AUTONOMOUS LEARNING IN UNIVERSITY STUDIES
}

\author{
Ilona Tandzegolskiene \\ Ausra Rutkiene \\ Vytautas Magnus University, Lithuania
}

\begin{abstract}
An appropriate and considerate choice of the study methods is an important condition for successful organization of the student learning process. A teacher can contribute to the common skills' development and student's autonomy by thoroughly combining various methods. This specific approach not only makes the learning process more interesting and encourages student's participation, but is also associated with student's responsibility, self-control and motivation, skills of learning process regulation, gained experience, learning planning and creation of appropriate learning environment. The study shows that teachers emphasize the importance of tools, methods and teacher-student cooperation. In the discussion of the tools and methods which enhance student autonomy during the studies, it is suggested to change traditional lectures by experiments, case studies, learning from experience, scientific projects, i.e., when students are engaged into interesting and long term activities which are practice-oriented, develop knowledge and help to gain experience.
\end{abstract}

Keywords: autonomous learning, teachers, autonomous work.

\section{Introduction}

Autonomous learning requires certain abilities which should be present or developed: learning ability, team work, time and resource management, research planning and carrying out, analytical thinking, problem analysis, search for solutions and information, work with existing information, etc. The research carried out by Zydziunaite and Tereseviciene (2012) revealed that when learning autonomously the students learn from the existing experience, reflect both successful and unsuccessful study experiences, consider autonomous learning tasks meaningful. However the negative aspect is that superficial learning concept prevails in students attitude, they also lack feedback from the teachers as well as motivation to perform given tasks which cover theoretical aspects. Students also experience tension, feel helpless if they fail to perform the tasks or don't answer the questions, are not able to plan the time necessary to perform the task and have difficulties in solving the problems which occur. It is noted that according to students' understanding autonomous learning encourages them to be more active and develops critical thinking.

Research questions: which learning methods development of autonomous learning are actual at university? 
The object of the research is autonomous learning.

The purpose of this research - to define the components which develop students' autonomous learning.

The research was done while applying several methods - the analysis of literature and interview. The analysis of qualitative data was done through the transcription of texts and creation of categories.

The qualitative research was performed in March - April, 2013. The participants of the research (interview) were teachers (total 20). The main aim of the research was to define what kind of method combinations help to develop common abilities which are important for autonomous learning as well as to find out what kind of tasks are formed by teachers, how the feedback of learning outcomes is organized, how the teacher's and student's relationship is maintained, what kind of means are used to ensure the maintenance and manifestation of common and subject abilities. The interview method was used to describe the situation of students' autonomous learning development during their studies at university. The questions were based on the articles which were prepared by various authors (Tandzegolskiene \& Pileckaite, 2010; Tandzegolskiene et al., 2010; Stasiunaitiene et al., 2012; Rutkiene \& Tandzegolskiene, 2012, 2013, Tereseviciene et al., 2012). A semi - structured interview was applied aiming that the interview was purposeful and a list of questions which directed the conversation on the following aspects was designed:

1. The concept of autonomous work and autonomous learning during university studies.

2. The level of autonomy while studying and the factors which enhance autonomous learning.

3. The means and the methods which enhance students' motivation to study and act autonomously.

Trying to find out the teachers' who work at university opinion about the manifestation of students' autonomous activities and their principles at university studies the following informants were enquired:

1. The representatives of Humanitarian sciences (6 informants: IF1, IF7, IF8, IF16, IF19, IF20).

2. The representatives of Social sciences (7 informants: IF3, IF9, IF10, IF13, IF14, IF15, IF18).

3. The representatives of Technological sciences ( 7 informants: IF2, IF4, IF5, IF6, IF11, IF12, IF17).

While performing an interview a snow ballprinciple and the main criteria that a teacher has to be at university no less than two years was used. The teachers from Vytautas Magnus (9 informants), Mykolas Romeris (3 informants), Aleksandras Stulginskis (4 informants) and Lithuanian Education (4 informants) universities took part in the research. 


\section{The concept of autonomous learning at university}

According to the idea of Grow (1991), (Tereseviciene et al., 2012) it is emphasized that autonomous learning level defines student's involvement into learning activities:

- $\quad$ Dependent student;

- Interested student;

- Involved student;

- $\quad$ Autonomous student.

Table 1. The concept of autonomous learning in university studies

\begin{tabular}{|c|c|c|}
\hline Confirming statements & Sub-category & Category \\
\hline $\begin{array}{l}\text { Students are offered more options to choose time } \\
\text { though it is indicated how many hours they have } \\
\text { to work and the form of work, but the teacher } \\
\text { doesn't evaluate these hours thus the student has } \\
\text { more responsibility to work and try to achieve the } \\
\text { foreseen goals. (IF 15). }\end{array}$ & $\begin{array}{l}\text { More options for } \\
\text { students }\end{array}$ & \multirow[t]{4}{*}{$\begin{array}{lr}\text { Perception } & \text { of } \\
\text { autonomy and } & \text { and } \\
\text { division } & \text { of } \\
\text { work load } & \end{array}$} \\
\hline $\begin{array}{l}\text { Looking from the current perspective students } \\
\text { perceive autonomous learning as free time and } \\
\text { possibility to do what they like and want. It is not } \\
\text { emphasized the type of activity which should be } \\
\text { performed, the requirements for the assessment, } \\
\text { what issues the students should focus on while } \\
\text { planning autonomous work time and energy. } \\
\text { (IF9). }\end{array}$ & $\begin{array}{l}\text { Clear perception of } \\
\text { work time. }\end{array}$ & \\
\hline $\begin{array}{l}\text { It is important both for the teachers and the } \\
\text { students to understand clearly the essence of } \\
\text { autonomous work and to define the criteria which } \\
\text { are important for such work, as well as to define } \\
\text { the limits, i.e. what is done by the teacher and by } \\
\text { the student, when they cooperate and when there } \\
\text { is no cooperation. Speaking about autonomous } \\
\text { work from the teacher's side, it is important to } \\
\text { help the student to prepare autonomous work } \\
\text { plan including the activities which the student has } \\
\text { to perform during the term, the lectures or } \\
\text { autonomously. (IF9). }\end{array}$ & $\begin{array}{l}\text { Interaction } \\
\text { teaching } \\
\text { learning. }\end{array}$ & \\
\hline $\begin{array}{l}\text { The most important advantage is the increase of } \\
\text { student's responsibility allowing the student to } \\
\text { understand that the attitude towards him is as to } \\
\text { a responsible grown-up person, able to take } \\
\text { responsibility for his behavior, actions and } \\
\text { choice. (IF 15). }\end{array}$ & $\begin{array}{l}\text { Increase of student's } \\
\text { responsibility. }\end{array}$ & \\
\hline
\end{tabular}


In this case autonomous learning is associated with motivation and desire to learn due to some internal interests and personal goals. According to Warring (2007), (Tereseviciene et al., 2012), autonomous learning can be developed and improved and the mentioned levels demonstrate the need for development/improvement of important abilities necessary for autonomous learning. This aspect is partially enhanced by interpretation of the interview results (see Table 1).

It is noted that after recalculation of teachers' working hours and students' autonomous work hours, the number of students' autonomous work hours has increased. It is also stated that there are not enough researches which would help to understand how much time the students really spend doing homework and given tasks. The teachers suggest to perform the research of students' needs and expectations which would help to plant and improve the tasks for students' autonomous work, depending on the time devoted for the performance of the task, selected method, evaluation, compatibility between the task goal and task conformity to students' and practical application needs.

Speaking from the teacher's perspective the importance of planning and clear presentation of task sequence plan for the term is emphasized. It includes work during lectures, team work, performance of individual tasks while preparing for assessments and autonomously performed tasks which are usually not evaluated and are incorporated into the learning process. In this case it is important to define who has to control the quality of autonomously performed tasks, the way these tasks have to be presented and how it affects student's assessments and final results, evaluating the subject in cumulative score system.

During the interview it was noted that the participating teachers give different definitions of students' autonomous activities during studies. Summarizing interview participants' thoughts, the following definitions are identified: autonomous studying, autonomous learning, autonomous activity, autonomy, autonomous work during studies. This demonstrates that there is no common opinion and commonly used single definition.

Some sources also indicate a few most frequently used definitions which describe students' autonomy idea - autonomous learning, self-learning, autonomous activity, autonomy (Butkiene \& Kepalaite, 1996; Tereseviciene et al., 2004; Lauzackas et al., 2008; Tandzegolskiene et al., 2010; Tandzegolskiene \& Pileckaite, 2010; Tereseviciene et al., 2012; Zydziunaite \& Tereseviciene, 2012; Stasiunaitiene et al., 2012; Rutkiene \& Tandzegolskiene, 2012; Rutkiene \& Tandzegolskiene 2013). Zydziunaite and Tereseviciene (2012) emphasize the lack of research in Lithuania which would analyze the concept of students' autonomous learning and autonomy when the autonomous learning is theoretical. Analyzing the sources of foreign literature a big variety of definitions of autonomy during studies is also found. For example German literature sources indicate such definitions as selbstgesteuertes Lernen, selbstorganisierte Lernen, selbstbestimmtes Lernen stating that these definitions 
are used in school pedagogy, pedagogical psychology, grown-ups education, university studies and personnel training process (Messner \& Blum, 2006; Knowles, 2007; Straka, 2008). According to Messner and Blum (2006) the existing variety of definitions while the emphasis is placed on student's self determination level, motivation, organization of learning process, responsibility and assessment supposes that these definitions reveal in fact similar things which describe student's activity. Therefore the authors suggest to use these definitions as synonyms and to emphasize student's autonomy level, responsibility, interactive learning and motivation. Analyzing the definitions by the English authors the following terms are found: self-directed learning (Knowles, 1975), self-planned learning, learning projects, self-education, selfteaching, autonomous learning, autodidaxy, independent study, open learning (Hiemstra, 2006). According to Zydziunaite and Tereseviciene (2012) these definitions, when translated to Lithuanian, don't reveal the real structure of autonomous learning and are not clearly defined on both international and national levels, i.e. the researches don't reveal firm relation between student's motivation, common skills, autonomous learning, knowledge development, reflection and responsibility.

An appropriate and considerate choice of the study methods is an important condition for successful organization of the student learning process which guarantees a self-sufficient, responsible and constantly evolving personality formation (Jakube \& Juozaitis, 2012). A teacher can contribute to the common skills' development and student's autonomy by thoroughly combining various methods. This specific approach not only makes the learning process more interesting and encourages student's participation, but is also associated with student's responsibility, self-control and motivation, skills of learning process regulation, gained experience, learning planning and creation of appropriate learning environment.The study shows that the teachers emphasize the importance of the tools, methods and teacher-student cooperation (see Table 2).

Table 2. Tools and methods which encourage students to continuously develop and act autonomously in their studies

\begin{tabular}{|c|c|c|}
\hline Supporting claims & Sub-category & Category \\
\hline $\begin{array}{l}\text { It would be good to change the thinking of students } \\
\text { that they learn not for a better mark or because they } \\
\text { are forced to, but for themselves and for their life. } \\
\text { Student self-dependence can be encouraged by } \\
\text { activities which do not have written answers in } \\
\text { textbooks. The answer has to be worked out logically } \\
\text { and the student has to prepare an individual answer. } \\
\text { Unfortunately, this is "unattainable" for the majority } \\
\text { of the students. (IF15). }\end{array}$ & $\begin{array}{l}\text { Naming of } \\
\text { external } \\
\text { motivation }\end{array}$ & $\begin{array}{l}\text { Application of } \\
\text { methods during } \\
\text { the study } \\
\text { process }\end{array}$ \\
\hline
\end{tabular}




\begin{tabular}{|c|c|}
\hline $\begin{array}{l}\text { To encourage the students to make decisions and } \\
\text { involve them in creative tasks such as participation in } \\
\text { various research projects, case studies or scenario } \\
\text { creation. You can also use models, examples, } \\
\text { illustrations, analogies, reflections, generalizing } \\
\text { conclusions, presentations, open discussions, } \\
\text { discussions with practitioners, SWOT, TOWS, problem } \\
\text { and task trees, portfolios, and other activities. (IF4). }\end{array}$ & $\begin{array}{l}\text { Engagement } \\
\text { into scientific } \\
\text { projects }\end{array}$ \\
\hline $\begin{array}{l}\text { Ideally, the student is motivated and waits for the } \\
\text { teacher to give certain guidelines: search there, be } \\
\text { interested in this... it is similar to treasure hunt: if you } \\
\text { go to point A, you will find the link to point B, and in } \\
\text { this way, you will find a treasure. But if a student is } \\
\text { not interested, if a student chooses the speciality only } \\
\text { because it was parents' decision, it will be different. } \\
\text { The student will put minimal effort only enough to } \\
\text { secure a positive mark and will not try to develop } \\
\text { autonomously or achieve more. (IF10). }\end{array}$ & $\begin{array}{l}\text { Maintenance } \\
\text { of interest in } \\
\text { activities }\end{array}$ \\
\hline $\begin{array}{l}\text { A teacher and a student are partners constructively } \\
\text { working in one direction - knowledge acquisition. This } \\
\text { is the main stimulus for self-sufficiency. Both partners } \\
\text { must have the same aspirations and desires. (D5).The } \\
\text { teacher prepares an outline or methodology of an } \\
\text { individual work which the student performs from } \\
\text { beginning to end by consulting with the teacher and } \\
\text { presenting the results in class. (IF16). }\end{array}$ & $\begin{array}{l}\text { A teacher as an } \\
\text { advisor and } \\
\text { counselor }\end{array}$ \\
\hline $\begin{array}{l}\text { A teacher can find the means to "compensate" for the } \\
\text { individual work and to make an effort to engage } \\
\text { students in such a way that they would want to work } \\
\text { autonomously without any compensation. Also, it is } \\
\text { possible to ask appropriate questions and tasks } \\
\text { (homework). The students' role depends on their } \\
\text { personalities. Some "nerds" tend to analyze the } \\
\text { material more in-depth than other students even } \\
\text { without any compensation. (IF2). }\end{array}$ & $\begin{array}{l}\text { Important } \\
\text { students' role }\end{array}$ \\
\hline $\begin{array}{l}\text { Students can be offered to search for more information } \\
\text { on a particular topic (for example, to write a summary } \\
\text { of the newest articles on a particular topic). However, } \\
\text { mostly the students get involved if the activity is } \\
\text { "rewarded" - it is given a part of the grade. This is a } \\
\text { "forced" way. If there is no reward, motivation is } \\
\text { usually also lower. (IF2). }\end{array}$ & $\begin{array}{l}\text { Motivation } \\
\text { enhancement }\end{array}$ \\
\hline $\begin{array}{l}\text { Most probably in this period of development and } \\
\text { enhancement of study programs, we should } \\
\text { concentrate on the understanding of individual work } \\
\text { and its application in preparing the students for the } \\
\text { actual professional activities. (IF 12). }\end{array}$ & $\begin{array}{l}\text { Dialogue } \\
\text { oriented at } \\
\text { labor market } \\
\text { needs }\end{array}$ \\
\hline
\end{tabular}


Knowledge is mostly acquired when students are active: they debate, teach each other, analyse, etc. The diversity of teaching methods and the change in the teaching paradigm which emphasises a student-directed teaching and holistic approach altered the understanding of the role of the teaching/ learning methods as mediators between teachers and students (Daugviliene \& Ruzevicius, 2009; Visockiene \& Puskunigiene, 2012). In the discussion of the tools and methods which enhance the student autonomy during the studies, it is suggested to change traditional lectures by experiments, case studies, learning from experience, scientific projects, i.e., when the students are engaged into interesting and long term activities which are practice-oriented, develop knowledge and help to gain experience. It is also suggested to organize discussions on the analyzed topic and invite real practitioners, to write essays, scenarios, apply the existing models, and organize simulation games. It is especially important that the students would understand the meaning of the task and would not participate only because of evaluation. Thus an interesting task performed by a student may become a useful future-oriented experience. Emphasis is also placed on constructive and continuous student consultation. According to Peilakauskaite and Varanauskas (2011) a student-directed teaching implies helping students to discover their own learning styles, to understand their needs and level of motivation and to gain effective learning skills that will be useful throughout their life. The application of this approach in practice would mean that teachers should help students to set achievable goals, to encourage students to assess themselves and their colleagues, to help students to work together in groups and to ensure that they use all available learning resources.

The interviewed teachers also note that attention should be shifted from the methods which enhance student autonomy to the understanding of independent activities, students' professional knowledge and readiness to enter the labor market. Student and teacher cooperation, when the topics relevant for the students are analyzed or different forms of knowledge testing are negotiated, is marked as a very important part of the study process related to the quality of higher education. In this way, the teacher discusses and considers students' requests. As to the level of autonomy in performing the tasks, it is emphasized that a teacher is a consultant or an advisor who encourages and motivates students to work more for their own benefit, whereas a student is responsible for activity organizing and time management.

Summarizing it can be stated that the involvement of the students into the studying process is especially important. It is mostly associated with students' cooperation, student and teacher discussions, problem analysis and search for solutions. The teaching methods should help the student to develop, enhance critical and analytical thinking, encourage inner motivation and be oriented at the practical application of knowledge. 


\section{SOCIETY. INTEGRATION. EDUCATION. Volume I}

\section{Conclusions}

In the teachers' opinion the autonomous learning enables the students to make decisions, to think critically and creatively, to comprehend the norms and boundaries of students' community, to choose an appropriate form of actions, to foresee the aims of learning and to choose the necessary means and methods to achieve the set goals. The following elements are the integral parts of autonomous learning: a) ability to organize a learning process autonomously; b) ability to observe and change this process; c) ability to evaluate a learning process critically; d) ability to reflect and evaluate the usefulness of the activity and the gained results. While trying to achieve that the students could work and learn autonomously during their studies, it is necessary to prepare involving tasks which would enhance students' interest, stimulate their motivation and would direct them to the common subject/study results. Moreover, the possibility to get the feedback during the studies, knowledge about time management while performing tasks as well as consultations with a teacher are of great significance too. The teachers emphasize that focusing on the students' opinions cognitive learning theory prevails which determines mentorconsultant's importance and an active information processing. According to the students, the most suitable situation for them is when study aims and subject learning outcomes are clearly set, but they prefer to choose themselves the methods for the achievement of the learning outcomes.

\section{References}

Butkienė, G. \& Kepalaitè, A. (1996). Mokymasis ir asmenybès brendimas. Vilnius: Margi raštai.

Daugvilienè, D. \& Ruževičius, J. (2009.). Studiju kokybe Bolonijos proceso kontekste. Downloaded from: http://ttvam.lt.gvazdikas.serveriai.lt/uploads/documents/leidiniai versl_teis_akt t1/1198.pdf(active: 2014-03-18).

Hiemstra, R. (2006). Is the Internet Changing Self-Directed Learning? Rural Users Provide Some Answers. International Journal of Self-Directed Learning, 3 (2) (p.p. 45-60). Florida: Atlantic University.

Jakubė, A. \& Juozaitis, A. (2012). Bendruju kompetenciju ugdymas aukštojoje mokykloje. Vilnius: Vilniaus universitetas.

Knowles, M. S. (1975). Self-Directed Learning: A Guide for Learners and Teachers. New York, Cambridge: The Adult Education Company.

Knowles, M. S. (2007). Lebenslanges Lernen (p.p. 177-178). München: Elsevier GmbH, S.

Laužackas, R., Stasiūnaitienè, E., Teresevičienè, M. (2005). Kompetenciju vertinimas neformaliajame ir savaiminiame mokymesi. Monografija. Kaunas: Vytauto Didžiojo universitetas.

Messner, R. \& Blum, W. (2006). Selbstständiges Lernen im Fachunterricht - sieben Projekte zur empirischen Unterrichtsforschung. In I. Mammes, S. Rahm, M. Schratz (Eds.). Schulpädagogische Forschung - Unterrichtsforschung - Perspektiven Innovativer Ansätze (p.p. 107-123). Innsbruck: Studien Verlag. 
Peilakauskaitè, K. \&Varanauskas, A. (2011). Studiju programu atnaujinimas: studentu vaidmuo diegiant ir tobulinant kompetencijomis grista ir i studenta orientuota studiju sistema. Vilnius: Kriventa.

Rutkienè, A. \& Tandzegolskienè, I. (2012). Manifestation of Students' Independent Activity during University Studies in Social Sciences. LICE-2012: London International Conference on Education (LICE-2012), London, UK: Proceedings. London: Infonomics Society, 113-115.

Rutkienè, A. \& Tandzegolskienè, I. (2013). Students' Ability to Act Independently in University Studies. Journal of International Scientific Publications: Educational Alternatives, 11 (1), 190-205. Bulgaria: Info Invest Ltd. Downloaded from: http://www.scientific-publications.net/download/educational-alternatives-2013-1.pdf (active: 2015-02-20).

Rutkienè, A. \& Tandzegolskienè, I. (2014). Studentu savarankiškumo skatinimas studijuojant universitete. Kaunas: Vytauto Didžiojo universitetas, Aurejus.

Stasiūnaitienè, E., Tandzegolskienè, I., Rutkienè, A. (2012). Development of Career Management Abilities for the Increase of University Graduates' Employability. UFHRD 2012 - 13th international conference on Human Resource Development Research and Practice across Europe: The Future of HRD - 2020 and Beyond: Challenges and Opportunities, May 23-25, 2012, Lisbon: Proceedings / Rui Silva, E. Tomè (Eds.), 409418. Lisbon: Universidade Lusíada de Vila Nova de Famalicão.

Straka, G. (2008). Selbstgesteuertes Lernen und Qualitat der Lehre. Universitat Bremen. Downloaded from: http://dppd.ubbcluj.ro/germ/neuedidaktik/artikel/2008/1\%20straka\% 20Lehrqualitaet.pdf(active: 20130407 ).

Tandzegolskienė, I. \& Pileckaite, R. (2010). Socialiniu mokslu srities studentu savarankiskos veiklos raiska universitetinese studijose. Pedagogika, Vilnius: Vilniaus pedagoginis universitetas, 97, 43-49.

Tandzegolskienè, I., Rutkienè, A., Pileckaitè, R. (2010). Savarankiskos veiklos samprata universitetinese studijose. Profesinis rengimas: tyrimai ir realijos $=$ Vocational Education: Research and Reality, Kaunas: Vytauto Didziojo universitetas, 19, 196-209.

Teresevičienè, M., Kaminskienė, L., Žydziūnaite, V., Gedvilienè, G. (2012). Savimoka ir savarankiskas mokymasis aukstojoje mokykloje: kritine diskusijos analize. Acta Pedagogika Vilnencia. Vilnius: Vilniaus universitetas, 29, 47-60.

Teresevičienè, M., Oldroyd, D., Gedvilienè, G. (2006). Suaugusiuju mokymasis. Kaunas: Vytauto Didžiojo universitetas.

Visockienè, O. \& Puskunigienè, A. (2012). Šiuolaikiniai mokymosi metodai. Kaunas: Technologija.

Žydžiūnaitè, V. \& Teresevičienè, M. (2012). Savarankiškas mokymasis - prasmingo dialogo tarp aukštosios mokyklos studento ir dèstytojo galimybės? Mokslo Lietuva, 10. Downloaded from: http://mokslasplius.lt/mokslo-lietuva/2012/2012/10/savarankiskasmokymasis-prasmingo-dialogo-tarp-aukstosios-mokyklos-studento-ir-destytojogalimybe/(active: 20130811$)$.

Žydžiūnaitè, V. \& Teresevičienè, M. (2012). Savarankiškas mokymasis - prasmingo dialogo tarp aukštosios mokyklos studento ir dèstytojo galimybės? Mokslo Lietuva, 10. Downloaded from: http://mokslasplius.lt/mokslo-lietuva/2012/2012/10/savarankiskasmokymasis-prasmingo-dialogo-tarp-aukstosios-mokyklos-studento-ir-destytojogalimybe/(active: 201308 11). 